Canadian Science Publishing

Canadian Journal of Earth Sciences Revue canadienne des sciences de la Terre

\title{
Crustal Accretion of Thick, Mafic Crust in Iceland: Implications for Volcanic Rifted Margins
}

\begin{tabular}{|r|l|}
\hline Journal: & Canadian Journal of Earth Sciences \\
\hline Manuscript ID & cjes-2016-0039.R1 \\
\hline Manuscript Type: & Article \\
\hline Date Submitted by the Author: & 27-Apr-2016 \\
\hline Complete List of Authors: & Karson, Jeffrey; Syracuse University, Department of Earth Sciences \\
\hline Keyword: & rifting, Iceland, hotspot, spreading \\
\hline & \\
\hline
\end{tabular}

\section{SCHOLARONE \\ Manuscripts}




\title{
Crustal Accretion of Thick, Mafic Crust in Iceland: Implications for Volcanic Rifted Margins
}

\author{
Jeffrey A. Karson \\ Department of Earth Sciences \\ Syracuse University, Syracuse NY 13244-1070
}

\begin{abstract}
Rifting near hotspots results in mantle melting to create thick, mafic igneous crust at Volcanic Rifted Margins (VRMs). This mafic crust is transitional between rifted continental crust with mafic intrusions landward and oceanic crust into which it grades seaward. Seismic velocities, crustal drilling, and exhumed margins show that the upper crust in these areas is composed of basaltic lava erupted in subaerial to submarine conditions intruded by downward increasing proportions of dikes and sparse gabbroic intrusions. The lower crust of these regions is not exposed but is inferred from seismic velocities $(\mathrm{Vp}>6.5 \mathrm{~km} / \mathrm{sec})$ and petrological constraints to be gabbroic to ultramafic in composition. Limited access to crustal sections generated along VRMs have raised questions regarding the composition and structure of this transitional crust and how it evolves during the early stages of rifting and subsequent seafloor spreading. Active processes in Iceland provide a glimpse of subaerial spreading with the creation of a thick $(40-25 \mathrm{~km})$ mafic igneous crust that may be analogous to the transitional crust of VRMs.
\end{abstract}

Segmented rift zones that propagate away from the Iceland hotspot, migrating 
transform fault zones, and rift-parallel strike-slip faults create a complex plate boundary zone in the upper, brittle crust. These structures may be decoupled from underlying lower crustal gabbroic rocks that are capable of along-axis flow that smooths-out crustal thickness variations. Similar processes may be characteristic of the early history of VRMs and volcanic hotspot ridges related to rifting and seafloor spreading proximal to hotspots.

Key words: rifting, Iceland, hotspot, spreading

\section{Introduction}

In a series of seminal papers, Kevin Burke and John Dewey (Burke 1977; Burke and Dewey 1973; Dewey and Burke 1974) linked Tuzo Wilson's ideas of hotspots and rifts to the development of continental margins. Their ideas created an important framework for more detailed studies of rifting and the development of continental margins that have followed. They noted that rifted margins initially form by the linkage of rift segments created at hotspots. A fundamental part of this model is that some parts of rifted margins develop near hotspots where voluminous, commonly alkalic, magmatism may precede or accompany rifting, whereas other margins form outside the influence of hotspots with little or no magmatism.

Investigations over the past few decades have shown that rifted continental margins are highly diverse with large variations in the degree of stretching of continental crust, the geometry of extensional structures, depositional patterns and amount of magmatic material generated during rifting (Franke 2013; Peron- 
Pinvidic et al. 2013; Reston 2009). This diversity mirrors that of continental rifts from which rifted margins develop (Rosendahl 1987; Sengor and Burke 1978).

\section{Volcanic Rifted Margins}

Some continental rifts develop by stretching and thinning of diverging continental edges with a negligible amount of pre- or syn-rift magmatism, for example, the western branch of the East African Rift (Ebinger 1989; Rosendahl 1987). In some cases continued divergence results in extreme attenuation of crustal lithologies and even exposure of mantle rocks prior to the onset of seafloor spreading (Peron-Pinvidic et al. 2013). Steep, seaward-dipping normal faults and detachment systems control the deposition of the syn- to post-rift sedimentary sections. There is commonly an abrupt onset of seafloor spreading and generation of oceanic crust at the seaward edge of these margins marking the continent-ocean transition.

In contrast, rifting in areas of elevated mantle temperatures results in decompression melting and the generation of basaltic magma (White and McKenzie 1995; White and McKenzie 1989; White et al. 1987). Continued divergence and magmatism result in the creation of a thick mafic crust (commonly $>20 \mathrm{~km}$ ) with a seismic structure that is transitional to more normal oceanic crust (Fig. 1), typically $\sim 7 \mathrm{~km}$ thick (Bown and White 1994). At these types of Volcanic Rifted Margins (VRMs) intervals of thick mafic crust can be 10s to 100 s of kilometers wide and can extend for 100 s of kilometers along the 
margins (Franke 2013; Geoffroy 2005; Menzies et al. 2002), making them some of the largest igneous provinces (LIPs) on Earth (Coffin and Eldholm 1994).

Seismic reflection surveys commonly identify distinctive seaward-dipping reflectors (SDRs) in the upper crust (UC) of these areas. SDRs consist of stacked, off-lapping, convex-upward, wedges of relatively high-velocity crust $(\sim 6.5 \mathrm{~km} / \mathrm{sec})$ that thicken seaward as their dip increases (Larsen and Jakobsdóttir 1988; Mutter 1985). The individual layers are tens of kilometers long and have an aggregate thickness of several kilometers. Correlation with onshore basaltic lavas, drilling, and seismic velocities all support the interpretation that SDRs are mainly subaerial lava flows that pass laterally into submarine lavas of the adjacent oceanic crust. Flood basalts form on surfaces with slopes of $1-2^{\circ}$, so the dipping lava assemblages must have been tectonically rotated after they were erupted. SDR packages are commonly interpreted as subaerial basaltic lava flows, in part because of the lateral continuity of the flows that is not expected in submarine eruptions (Planke et al. 2000). However, high effusion rate submarine lavas from the Hawaiian Arch have lobate forms on the surface of flows that are laterally continuous for tens of kilometers (Lipman et al. 1989). So SDRs do not necessarily signal subaerial eruptions.

The geometry of SDRs suggests progressive subsidence of the locus of magmatism that moved seaward relative to the rifted margin during spreading. The lower crust (LC) beneath SDRs has relatively high seismic velocities (>6.5 
$\mathrm{km} / \mathrm{sec}$ ) that correlate with gabbroic rocks but also overlap with the range of velocities of lower crustal continental rocks and other lithologies (Holbrook and Keleman 1993). Thus, the nature of the lower crust at VRMs has been a matter of continuing debate.

The composition and mode of construction of VRMs are relevant to understanding some of the largest fluxes of magma and energy from the Earth's interior to the surface as well as to reconstructing various stages of development of rifted margins. In order to gain some insight into the composition and internal structure of thick mafic crust of VRMs it is useful to consider the range of processes known from accretion of oceanic crust at mid-ocean ridge spreading centers and in subaerial spreading environments like Iceland. Active spreading environments are advantageous in that they reveal ongoing processes and lack extensive overlying sedimentary sections that typically hide the deep crustal structure of VRMs.

\section{Thick Mafic Crust}

Where rifting occurs above mantle hotspots very large volumes of basaltic magma are generated. Some of this material is intruded into the rifted continental crust but much of it builds a thick, mafic, igneous crust that is transitional to oceanic crust as seafloor spreading is established. Where hotspots remain beneath spreading ridges, a swath of relatively thick oceanic crust extends from the spreading center to the thick magmatic crust of the VRM, tracking the plate 
movement relative to the hotspot as spreading proceeds. The internal structure of these ridges is different from that of other volcanic island and seamount chains in which hotspot magmatism is superimposed on older lithosphere rather than modifying spreading processes at a mid-ocean ridge (MOR).

At VRMs crustal construction may resemble a scaled-up version of seafloor spreading. So models of seafloor spreading may provide some insight into the construction of the thick mafic crust of VRMs. Several investigators have used models of seafloor spreading based on the internal structure of ophiolite complexes in considering accretion processes at VRMs (Holbrook and Keleman 1993; Kelemen and Holbrook 1995; Korenaga et al. 2002; Maclennan et al. 2003; Maclennan et al. 2001). Subaerial spreading that creates a thick mafic igneous crust above the Iceland hotspot bridges the gap between these extremes.

There is great diversity in the oceanic crust as a function of the volume of magma delivered to the crust per unit of spreading referred to as the magma budget (Karson et al. 2015). In areas of low magma budget, typical of slow-spreading environments, the oceanic lithosphere experiences stretching with little magmatic construction resulting in highly faulted and altered crust and mantle, and in some cases oceanic core complexes. Highly stretched crustal sections can be punctuated by less damaged volumes of crust formed by pulses of magmatism creating a highly heterogeneous crust on a regional scale. At higher magma budgets, typical of intermediate rate to fast-spreading centers, a relatively simple 
layered mafic crust is constructed (Karson et al. 2015). Oceanic crust formed at high magma budgets may be relevant to understanding how much thicker mafic crust forms at VRMs. Crustal accretion in Iceland represents spreading at an extremely high magma budget, comparable to that of fast-spreading mid-ocean ridges, despite its slow spreading rate of $\sim 20 \mathrm{~mm} / \mathrm{yr}$. (Einarsson 2008).

Regardless of setting, basaltic magma delivered to the surface builds the crust by two different processes controlled by the depth and temperature of magmatic emplacement to create an upper and lower crust. The upper crust consists of lava flows fed by dikes and commonly a sheeted dike complex of nearly $100 \%$, side-by-side, sheet-like intrusions. Variations on this theme occur in ophiolites, oceanic crust, Iceland, VRMs. The geometry and internal structure of these units provide important keys to understanding how the upper crust is constructed in different environments and can have implications for deeper level processes.

The lower crust is not as well known across this spectrum of spreading environments, but based on ophiolite complexes, it appears to be constructed by incremental intrusion of magma that may be deformed by high-temperature, solid-state (or magmatic) flow during accretion during spreading. Different modes of intrusion and deformation kinematics have resulted in a range of models for the construction of the middle to lower crust (Boudier and Nicolas 2011; Kelemen et al. 1997; Quick and Denlinger 1993). 
Although there are numerous potential pitfalls in correlating seismic structure to the geology of the oceanic crust, the seismic structure provides some general constraints. The seismic thickness of oceanic crust is on average $\sim 7 \mathrm{~km}$ (Bown and White 1994). In general, the upper part of the oceanic crust, commonly referred to as seismic layer 2, is composed of $1-2 \mathrm{~km}$ of basaltic lavas and dikes of very similar composition with compressional seismic velocities of 4 to $\sim 6.5$ $\mathrm{km} / \mathrm{sec}$. Rapidly increasing velocity with depth is interpreted to be primarily related to the closure of cracks with increasing pressure and mineralization. The base of layer 2 has been interpreted as a boundary between upper and lower crustal rocks, an alteration front, and a horizon where crack porosity rapidly decreases (Christeson et al. 1994). In drilling and direct observations of the upper oceanic crust, all of these relationships occur in close proximity (Karson et al. 2015).

The lower crust is composed of broadly gabbroic rocks. Heterogeneous gabbros with variable textures and bulk compositions similar to the upper crust pass downward into layered gabbroic rocks with higher $\mathrm{MgO}$ contents. The layering is the product of igneous cumulate processes, compaction, concordant sheet-like intrusions, and high-T flow and melt segregation. Gabbroic rocks have seismic velocities of $>6.5-7.2 \mathrm{~km} / \mathrm{sec}$, defining seismic layer 3 . Layer 3 in oceanic crust and gabbroic units in ophiolites typically have thicknesses of $4-5 \mathrm{~km}$. 
In ophiolites ultramafic igneous rocks, including dunites and wehrlites, produced as part of the same process, are common in the lower part of the igneous crust. These lithologies have rarely been recovered from the oceans. They are commonly interlayered with gabbroic rocks and in some cases occur as layered units tens to hundreds of meters thick. The seismic velocities of these olivine-rich lithologies overlap with those of underlying residual mantle peridotites upon which the magmatic crust rests. From a seismic perspective, ultramafic magmatic rocks would be below the Moho discontinuity. Thus, if ultramafic magmatic rocks occur in oceanic crust, the seismic thickness of the crust will not correspond to the magmatic thickness. This has implications for both the bulk composition of the crust as well as assessing variations in magma production rates along spreading centers as well as VRMs.

Despite the ambiguities noted above, the seismic velocity structure of the crust formed in different environments provides a useful basis for comparison. Crustal seismic velocity sections show some systematic variations with a clear distinction between the UC and LC. UC has lower seismic velocities $(\mathrm{Vp}<6.5 \mathrm{~km} / \mathrm{sec})$ and steep velocity gradients in contrast to the higher velocities and very gentle vertical gradients of the LC. With increasing total crustal thickness, for example, near hotspots, the proportion of upper crust (Layer 2) decreases. The increase in total crustal thickness is a result of increasing lower crustal (Layer 3) thickness implying more intrusive than extrusive construction (Mutter and Mutter 1993). 
The proportion of lower to upper crust (LC:UC) is highly variable among magmatic crustal sections formed in different environments. Petrologic arguments suggest that there should be at least as much fractionated intrusive material as extrusive upper crustal material (Cox 1980), but this is a minimum. Therefore, basaltic lava units on VRMs imply at least an equal thickness of intrusive material deeper in the crust or perhaps dispersed in the mantle. The ratio of LC to UC is 2:1 to 3:1 in normal oceanic crust (Bown and White 1994) and ophiolites (Casey et al. 1981; Moores and Vine 1971; Nicolas 1989). Globally, crustal velocity sections from thick oceanic crust, including VRMs, show a large range of ratios with LC thickness generally greater than that of the UC and many sections with ratios of 2:1 to 4:1 (Mutter and Mutter 1993).

It is not clear why this wide variation exists. It seems possible that conductive and hydrothermal cooling create an insulating lid, permitting crustal thickening by intrusion with limited growth of the overlying lid. The spatial distribution of LC construction is also likely to be important. Focused intrusion at a shallow level beneath a spreading axis can be cooled by localized hydrothermal systems, whereas intrusion over a wider, deeper region of the crust would tend to keep the LC hotter longer (Maclennan et al. 2005). If the LC is constructed more rapidly than it is cooled, it could flow beneath the UC resulting in relative thickness changes. 
Models for MORB generation depend on assumptions of the composition of the mantle and the bulk composition of the magmatic crust. In most of these models fractionation of about $50 \%$ is required to produce melt of an appropriate basaltic composition. Generating more siliceous (rhyolitic) melts would require $\sim 90 \%$ fractionation. So for each kilometer of basaltic material, a thickness of $2 \mathrm{~km}$ of fractionated plutonic material would be expected and hence a LC to UC ratio of 2:1. Although a range of igneous processes could potentially affect this simple relationship, it is reasonable to first-order and it is in accord with the internal structure of the oceanic crust and ophiolites.

\section{NE Atlantic Crustal Structure}

The NE Atlantic region features a range of settings of magmatic crustal construction (Fig. 2) including conjugate VRMs of East Greenland to the NW and the Vøring- Rockall margins to the SE. The margins are bridged by a hotspot ridge, the Greenland-Iceland-Faeroe Ridge (GIFR), a swath of thick oceanic crust left in the wake of the Iceland hotspot. Thick oceanic crust occurs in the basins to the north and south of the GIFR. The seismic crustal thickness varies across the different tectonic settings (Fig. 3) reflecting somewhat different modes of crustal construction. In general, the UC and LC both increase as the total thickness of the crust increases. Most of the variation occurs in the lower crustal thickness (Mutter and Mutter 1993). 
Approaching Iceland from both the north and south along the Mid-Atlantic Ridge, the morphology of the spreading center and the crustal thickness change systematically as Iceland is approached. Rifted spreading centers, typical of the Mid-Atlantic Ridge, transition to axial morphologies more typical of faster spreading ridges with smooth, elevated forms proximal to Iceland (Searle et al. 1998). Oceanic crust formed on the Kolbeinsey and Reykjanes Ridges to the north and south of Iceland thickens toward Iceland reflecting elevated mantle temperatures of the hotspot (Hooft et al. 2006). In contrast to normal oceanic crust, typically $\sim 7 \mathrm{~km}$ thick, spreading on these ridges generates crust $>15 \mathrm{~km}$ thick that thins to close to normal thicknesses over $500 \mathrm{~km}$ along the spreading center (Bunch and Kennett 1980; Hooft et al. 2006; Smallwood et al. 1995).

The thickest crust in the region coincides with the hotspot beneath Iceland. The crust is $40 \mathrm{~km}$ thick directly above the center of the hotspot, thinning to $\sim 25 \mathrm{~km}$ thick across most of Iceland and beneath the broad platform that rings the island (Figs. 3 and 4). The lower crust is $\sim 35 \mathrm{~km}$ thick under central Iceland and decreases to $15-20 \mathrm{~km}$ thickness away from the center of the hotspot and beneath the Iceland platform (Brandsdóttir and Menke 2008; Darbyshire et al. 1998; Hooft et al. 2006).

On the VRMs to the NW and SE very thick, high-velocity (mafic) crust capped by upper crust with SDRs occurs seaward of rifted continental crust overlain by flood basalts and cut by basaltic dikes, sills, and plutons. The East Greenland margin 
is uplifted and exhumed to reveal a broad flexure zone where subaerial lava flows increase in dip seaward to near vertical orientations. Dikes at a high angle to the lavas rotate to near horizontal orientations. Later dikes cut the dipping ones demonstrating that the rotation and intrusion were broadly synchronous. Near the coast the dike density increases to nearly $100 \%$ in a sheeted dike complex marking the continent-ocean transition (Karson and Brooks 1999; Klausen and Larsen 2002; Nielsen 1978; Nielsen and Brooks 1981). Offshore, lavas and SDRs overlie mafic crust $\sim 30 \mathrm{~km}$ thick. The crustal thickness gradually decreases seaward to about $10 \mathrm{~km}$ in thick oceanic crust. Thicker oceanic crust underlies the Greenland-Iceland Ridge (Korenaga et al. 2000; Mutter and Mutter 1993). The crustal thickness along the Faeroe-Iceland Ridge decreases from Iceland to the SE. Crust to the north and south of the ridge is about $12-15 \mathrm{~km}$ thick (Bohnhoff and Makris 2004; Smallwood et al. 1999; White et al. 2008).

The systematic pattern of crustal thickness along the Reykjanes and Kolbeinsey Ridges is interpreted as a result of progressively elevated mantle temperatures approaching the Iceland hotspot (Hooft et al. 2006; Smallwood et al. 1995; White and McKenzie 1989). Variations in thickness in the thick, hot crust may be reduced by along-axis flow, mainly in the lower crust (Bell and Buck 1992). A similar process may apply on a larger scale to crustal accretion on the VRMs and hotspot ridges of the NE Atlantic. The observed variations may be the result of lateral flow and thinning of thick $(\sim 40 \mathrm{~km})$ mafic crust produced near the hotspot center to a thickness of about $25 \mathrm{~km}$ along hotspot ridges. Less thinning would 
be expected on the landward parts of VRMs where the lower crust consists of rifted continental lithosphere intruded by mafic dikes and plutons (Nielsen and Brooks 1981; White et al. 2008) that does not get hot enough to flow.

Alternatively, the thick crust of central Iceland might be interpreted as the result of a recent, anomalous rate of magmatic production that will not later be reduced in thickness.

\section{Icelandic Crust and Active Spreading Processes}

The thick mafic crust of Iceland and the processes that create it provide useful analogs for the magmatic crust of VRMs. Dynamic support by the underlying hotspot provides access to subaerial spreading processes. Glaciation has removed as much as $2 \mathrm{~km}$ of the lava pile providing a view of the upper crust. Extensive geological and geophysical studies (Brandsdóttir and Menke 2008; Einarsson 2008; Sæmundsson 1979, 1986) provide constraints on spreading processes that may apply broadly to the accretion of mafic crust of VRMs. Uplifted and glaciated exposures on the East Greenland margin show a somewhat deeper structural level near the ocean-continent transition helping justify this extrapolation.

\section{Upper Crust of Iceland}

The center of the Iceland hotspot lies beneath the highest point of the island marked by the Vatnajökull Icecap (Wolfe et al. 1997). The plate boundary zone is complex with the Eastern Rift Zone (ERZ) and Northern Rift Zone (NRZ) 
extending south and north from the hotspot, respectively (Fig. 4). The ERZ overlaps with the less active Western Rift Zone (WRZ) (Einarsson 2008). These active rift zones are linked to the Reykjanes Ridge to the south and Kolbeinsey Ridge to the north by transform fault zones. The transform offsets shift the plate boundary eastward relative to the regional trend of the MAR keeping the boundary centered on the hotspot (Einarsson 2008; Sæmundsson 1974, 1979).

The rift zones are composed of an array of overlapping, volcano-tectonic spreading segments, $10-20 \mathrm{~km}$ wide and 10s of kilometers long (Sæmundsson $1978,1979)$, analogous to spreading segments of MORs. Each segment consists of a magmatic center marked by a central volcano (Walker 1957, 1964) from which fissure swarms and underlying dike swarms extend along strike. Normal faults spaced 1 to $5 \mathrm{~km}$ apart commonly bound the segments creating shallow graben (Einarsson 2008; Sæmundsson 1986). The vertical displacement of the faults is difficult to constrain because they are growth structures, with accumulations of lava on the hanging wall blocks. Some have relief of as much as $150 \mathrm{~m}$. Collectively, these rift-parallel structures impart a strong anisotropy to the crust with closely spaced, roughly N-S, zones of weakness that may influence later tectonics. Unlike the simple linear arrangement of spreading segments on MORs, spreading segments that compose the post-glacial neovolcanic zone (NVZ) of Iceland have a complex, overlapping, en echelon arrangement 50 to $100 \mathrm{~km}$ wide (Hjartardóttir et al. 2012; Hjartardóttir et al. 
2015). Linkages between spreading segments are poorly exposed but include seismically defined accommodation zones (Green et al. 2014).

Exhumed sections of Tertiary crust to the east and west of the NVZ show dissected central volcanoes with dense cone sheets, gabbroic intrusions, granophyres, and high-T alteration (Sæmundsson 1979; Walker 1957, 1964). These are linked to dense dike swarms that can be traced for many kilometers along strike. Exhumed lavas dip gently toward the NVZ in a pattern similar to SDRs. Dikes, generally normal to the lava flows, dip in the opposite direction. The lavas generally dip less than $20^{\circ}$ toward the NVZ with wedge-shaped packages of lava thickening toward the NVZ. Horizontal zeolite zonation, assumed to have formed in a uniform horizontal geothermal gradient, is superimposed on the tilted lavas demonstrating that the tilting occurred before burial metamorphism (Walker 1960). The total thickness of the UC units in Iceland is not accurately known, but drilling in the most deeply exhumed areas shows that the lavas are at least $4.5 \mathrm{~km}$ thick (Pálmason et al. 1978).

Overall, the geometry of lava flows on Iceland is very similar to that of SDRs (Mutter 1985). The inward-dipping structure implies substantial subaxial subsidence and has inspired models of accretion in which the upper crust is constructed by thickening of the lava pile accommodated by subsidence centered on the axis and diminishing off axis with progressive spreading (Bodvarsson and Walker 1964; Pálmason 1986). Although lavas on Iceland typically do not dip 
more than $20^{\circ}$, lavas on the East Greenland margin bend downward to nearly vertical, demonstrating that larger rotations are possible at deeper structural levels.

Dikes in both Iceland and deeper structural exposures on Greenland are oriented at a high angle to the lava flows and rotate to low angle orientations as the lavas steepen. In the Tertiary crust of Iceland, major faults are not common, but in the deeper level exposures of East Greenland, landward-dipping normal faults commonly cut the lavas, dikes and pre-rift continental basement rocks (Karson and Brooks 1999; Klausen and Larsen 2002; Nielsen and Brooks 1981).

The same geometry, with inward-dipping lava flows and outward-dipping dikes, occurs in the much thinner upper oceanic crust formed at relatively high spreading rates (Karson 2002). This geometry is much less evident on the seafloor because of the discontinuous, lumpy form of most lava flows. Thus, the upper part of the oceanic crust and the UC of Iceland "grow downward" rather than upward (Einarsson 2008) with the lava pile thickening without generating substantial topographic relief. Collectively these observations suggest that a similar constructional process occurs in UC formed across a wide range of settings where magmatic construction dominates from volcanic rifts to VRMs to subaerial spreading in Iceland to mid-ocean ridge spreading centers. In all of these settings, the progressive subsidence of the lava pile must be accommodated by mass redistribution deeper in the crust. 
Both the ERZ and NRZ are propagating away from the hotspot (Fig. 4). This is most clearly seen in the way that young lavas and rift structures of the NVZ truncate the transform faults. To the south, the ERZ extends past the South Iceland Seismic Zone (Fig. 4). In the north, the NRZ cuts major strands of the Tjörnes Transform Zone. Both the propagating rift zones and transforms remain active reflecting the complexity of the plate boundary kinematics and the significant time required for its rearrangement. The well known 'ridge jumps' to the east in Iceland (Einarsson 2008; Garcia et al. 2002; Sæmundsson 1974) are a consequence of propagation of the rift zones and their transform offsets (Karson 2016).

As the rift zones propagate, the transform offsets at their tips migrate north and south leaving swaths of crust affected by transform fault deformation in their wakes. Transform fault displacements are mainly accommodated by 'bookshelf faulting' on numerous antithetic strike-slip faults oriented at a high angle to the main transform trend (Einarsson 1991). These faults commonly parallel local dike margins and therefore may be reactivated, spreading-related faults or other zones of weakness such as dike margins. Crustal blocks dominated by arrays of bookshelf faults are separated by discontinuities with transform-parallel trends. In some cases, these are discrete transform strike-slip faults but others appear to be boundaries that accommodate different amounts of faulting or rotations in crustal blocks to the north and south. 
Rift propagation results in varying amounts of spreading along rift zones and rotations about poles of rotation located at propagating rift tips (Karson 2015, 2016). The resulting block rotations in Iceland may account for a number of additional complications. For example, the northward propagation of the NRZ would result in clockwise rotation of crust to the west of the rift zone. This may explain the widespread development of NS (rift-parallel), sinistral, strike-slip faults across northern Iceland that cannot be related to abandoned transforms (Fig. 4). Similarly, the southward propagation of the ERZ may explain widespread dextral, rift-parallel strike-slip faulting. Rift-parallel strike-slip faults, at least east of the NRZ, do not have consistently dextral slip as would be predicted. This may be the result of migration of the locus of spreading across the NRZ resulting in the transfer of crustal blocks from west to east of the plate boundary zone or, possibly, multiple propagation events.

Propagation of the NRZ and ERZ away from the hotspot results in the opposite sense of rotation of microplate-like blocks to the north and south resulting in a component of divergence. Divergence between these crustal blocks may account for the poorly known Central Rift Zone (CRZ) that extends westward from the Iceland hotspot toward the Snæfellsnes Volcanic Zone (Fig. 4) (Karson 2015, 2016).

Lower Crust of Iceland 
Lower crustal rocks are not exposed on Iceland. A few gabbroic plutons intrude the deepest parts of the lava pile but are at structural depths of $\sim 2 \mathrm{~km}$. So only indirect information is available on the nature of the lower crust. The seismic thickness of the crust in Iceland ranges from $\sim 40 \mathrm{~km}$ near the center of the hotspot to a more typical thickness of $25 \mathrm{~km}$ in the Tertiary crust and beneath the Iceland platform (Darbyshire et al. 1998; Darbyshire et al. 2000b). Seismic velocities are consistent with the lower crust being composed of gabbroic rocks. The large thickness of basaltic UC strongly suggests a considerable thickness of differentiated gabbroic material (Cox 1980). Petrological investigations of Icelandic basalts and xenoliths indicated significant crystallization of olivine, clinopyroxene and plagioclase (Maclennan et al. 2003; Maclennan et al. 2001).

Given the geothermal gradient in the NVZ of $\sim 100^{\circ} \mathrm{C} / \mathrm{km}$, it would be expected that gabbroic material would be weak and ductile at depths of $<10 \mathrm{~km}$ (Hirth et al. 1998). This is consistent with the absence of seismicity in the lower crust of Iceland (Stefánsson et al. 1993) with the exception of active magmatic areas of the NVZ and the major transform fault zones (Jacobsdóttir 2008; Soosalu et al. 2010).

Jones and Maclennan (2005) argue that initially hot weak LC near the hotspot flows along-strike beneath the NVZ thereby decreasing the LC thickness. The LC thins to the north and south away from the hotspot for $>100 \mathrm{~km}$ creating the broad Iceland platform. The modified crustal thickness is frozen-in to the 
lithosphere as it spreads laterally away from the plate boundary. Isostatic adjustments to crustal thicknesses modified by the LC flow are reflected in the form of the Iceland platform (Fig. 2). Modification of original crustal thicknesses by LC flow would be superimposed on regional changes in the thermal structure and crustal thickness along the Mid-Atlantic Ridge (Hooft et al. 2006; Jones and Maclennan 2005; White and McKenzie 1989). Similarly, Bell and Buck (1992) interpreted the lack of segmentation in along-axis bathymetry and mantle Bouguer gravity anomaly of the Reykjanes Ridge as a result of lateral flow of hot, weak crustal material.

These types of changes in crustal structure should also be preserved in volcanic hotspot ridges with thick oceanic crust. Crust to either side of a hotspot ridge would be thickened by LC flow at the expense of initially thick crust in the center of the ridge. Bathymetry and crustal thickness variations across various parts of the Greenland-Iceland-Faeroe Ridge (GIFR) may reflect this process (Bohnhoff and Makris 2004; Korenaga et al. 2000; White et al. 2008).

Systematic changes in crustal thickness occur along the GIFR with the thickest crust beneath the Iceland hotspot $(\sim 40 \mathrm{~km})$ decreasing to $\sim 25 \mathrm{~km}$ along the hotspot ridge to the NW and SE. Thicker crust at the margins might be the result of a cooler, rifted continental edge where less LC flow was possible. 
For along-axis flow sufficient to reduce the LC thickness by $\sim 30 \%$ it is likely that the UC and LC would be decoupled. Thus, the tectonic processes described above for the UC might not reflect this deeper level flow (Fig. 5). Decoupling at different crustal levels is a general feature of tectonic settings where a rheologically weak crustal layer underlies a stronger, rigid upper crust (Axen et al. 1998; Hopper and Buck 1996; McKenzie et al. 2000; Royden and Burchfiel 1987). LC flow could help accommodate the subaxial subsidence required by the kinematics of construction of the overlying lava pile. Given the similarities in crustal structures along-axis LC flow is a potentially important factor in the development of thick mafic crust at VRMs. It is also possible that this process occurs along mid-ocean ridge spreading centers where the LC is hot enough to flow during spreading. Kinematic studies of the Oman Ophiolite demonstrate the importance of along-axis flow in the LC away from centers of mantle upwelling (Nicolas et al. 1996).

\section{Implications for VRMs}

The brief summary of UC and LC relations in Iceland and related areas points to a complex 3D mode of accretion with significant rift zone-parallel displacements and mass redistributions (Fig. 5). Similar UC structures in East Greenland provide a link to early stages of development of VRMs. These relationships suggest some possible features that might be expected at VRMs. In the context of the development of VRMs above mantle hotspots (Burke and Dewey 1973), the kinds of complications outlined above would be predicted in specific settings 
(Fig.6). By analogy with Iceland, there are some predictable relationships in VRM crust formed near hotspots and on volcanic ridges extending into adjacent oceanic crust.

Seismic data from Iceland and other areas of thick mafic crust show a range of ratios of thickness of LC to UC. If as in Iceland these areas were constructed rapidly enough to remain hot during extension, it likely that they have been modified by some amount of lateral flow, probably mainly along the axis. The same is likely to apply to oceanic crust formed at relatively fast-spreading ridges and to slow-spreading ridges near hotspots (Bell and Buck 1992). The possibility that the crustal structure could have been modified makes it difficult to know what the original LC to UC ratio might have been. Petrological considerations suggest that the ratio should be $1: 1$ at a minimum (Cox 1980) but that the initial proportion of LC could be much larger. In the young crust at the Iceland hotspot the ratio is $3: 1$ to $>7: 1$. During spreading this ratio could decrease as mobile LC flows from areas of thick crust into adjacent areas. Near a hotspot the LC thins at the expense of areas along the rift where the LC thickens. This process appears to occur on the scale of 100-200 km across Iceland. Similar along-strike variations should be expected on VRMs and also along the volcanic ridges produced by hotspot tracks. This mass redistribution would also transfer heat away from the hotspot center and cause isostatic adjustments to the areas with modified crustal thickness. Subsidence of areas from which LC has been removed could explain subaerial flood basalts in areas with crust that is too thin to have been above sea 
level when it was initially formed. In any case, reconstructions for VRM crust beneath SDRs must account for the corresponding LC material and possible gains or losses by along-strike flow.

Seaward-dipping subaerial flood basalts built on rifted pre-rift crust are different from true SDRs. The flood basalts probably dip seaward because of subsidence of the seaward edge of the rifted crust that has been massively intruded by dike swarms and mafic plutons (Fig.1). True SDRs probably only form above newly constructed thick mafic LC that is capable of lateral flow.

As the thick mafic crust is created at VRMs the UC, including SDR sequences are likely to be mechanically decoupled from underlying LC. SDRs form by progressive axial subsidence above the weak, ductile middle to lower crust. Rather than being driven by loading of basaltic material at the surface, subaxial subsidence in the UC may be controlled by outflow of LC along the axial zone.

Attempts to restore VRM UC structures typically result in space problems in the LC that may not be possible to reconcile with deformation of pre-rift crust. Models for the development of SDRs and VRM crust typically include landward-dipping faults to account for the seaward dip of originally horizontal lava flows and sediments (Geoffroy 2005; Karson and Brooks 1999), just the opposite of the kinematics of non-volcanic rifts and margins. One possibility is that these structures form in the upper plate of detachment systems that dip beneath the 
margin (Bohannon 1986; Bosworth 1987; Wernicke 1981). But this is unlikely where symmetrical VRMs develop, as in the NE Atlantic. Quirk and others (2014) proposed a model involving complex LC flow with a residual axial horst but this is not necessary if there is substantial axial mass redistribution. In Iceland where symmetrical, inward-dipping lava sequences occur at abandoned rifts, no old, residual structure is preserved (Garcia et al. 2003; Hardarson et al. 1997). Instead, these upper crustal structures have probably formed over a mobile LC (Pálmason 1986).

SDRs become less continuous with distance away from the rifted margin, as they pass laterally into oceanic crust. This may reflect a change from sheet-like subaerial lava flows that produce laterally continuous reflectors to less continuous submarine pillow lava flows. Oceanic crust formed at fast- to intermediate rates has inward-dipping lavas. Thus, thick VRM crust and oceanic crust may form by similar processes and produce similar structures at different scales. There may be a continuum of crustal structures ranging from thick VRM crust to thick oceanic crust of hotspot ridges to normal oceanic crust that reflect different magma budgets during spreading.

Wide rift zones similar to Iceland with arrays of spreading segments are more likely for VRMs than simple linear rifts like mid-ocean ridges. Parallel faults, fissures and dikes impart a strong mechanical anisotropy to the UC. Propagation away from hotspot centers results in complicated basement age relationships 
with apparent ridge jumps and migrating of transform offsets. Migrating transforms create waves of deformation in young basement rocks that may also affect overlying sedimentary accumulations.

Rift propagation also can result in rotation of crustal blocks over the weak ductile LC similar to microplates along spreading centers (Hey 2004). Block rotations in this anisotropic crust can result in strike-slip (bookshelf) faulting by reactivation of spreading-related discontinuities. These faults can affect overlying syn-rift sedimentary packages. The resulting out-of-plane movements on these riftparallel strike-slip faults would cause problems in balancing 2D cross sections (Elliot 1983; Gibbs 1983; Hossack 1979).

Where VRMs form near hotspots, thick mafic crust similar to that of Iceland may form. These would be likely places for the complex style of spreading outlined above (Fig. 6). Along-strike variations in the internal structure and composition of thick, mafic, igneous crust of VRMs is likely to be the result of complex accretion of the upper crust and along-axis flow of the lower crust that diminishes with distance from hotspots.

\section{Conclusions}

Accretion of mafic igneous crust can be viewed across a range of scales from oceanic crust to areas of thick oceanic crust on hotspot ridges, to volcanic rifted margins. Similar structures and accretionary processes appear to occur in all of 
these settings. Spreading processes in Iceland may be analogous to those of the early stages of accretion at VRMs. On this basis, there are some predictable features of VRMs near hotspots. One is the construction of a thick mobile mafic to ultramafic crust beneath a basaltic upper crust with SDRs. The upper crust is likely to have complex structures resulting from a wide zone of accretion, propagating rifts, migrating transforms and rotation of crustal blocks. These upper crustal structures are likely to be decoupled from the lower crust in which significant along-strike flow takes place. These results have implications for the reconstruction of VRMs, the thermal and mechanical evolution of the crust that forms in these environments, and the sedimentary units deposited on top of them.

\section{Acknowledgements}

Kevin Burke and John Dewey were the nucleus of the highly productive tectonics group at SUNY Albany in the 1970's and early 1980's. Those of us who were lucky enough to be graduate students there in that era have benefited from their inspiration through our entire careers. This paper is an outgrowth of just one of the many ideas they introduced at that time. I thank Bryndis Brandsdóttir, Páll Einarsson and Kristján Sæmundsson for their collaborations and insights into Icelandic geology. Roger Buck, Páll Einarsson and Richard Hey provided very useful reviews that helped improve this presentation. This work was supported in part by NSF grants: EAR 9508250 and OCE 1153497. 


\section{References}

Axen, G.J., Selverstone, J., Byrne, T., and Fletcher, J.M. 1998. If the strong crust leads, will the weak crust follow? GSA Today, 8(12): 1-8.

Bell, R.E., and Buck, W.R. 1992. Crustal control of ridge segmentation inferred from observations of the Reykjanes Ridge. Nature, 357: 583-586.

Bodvarsson, G., and Walker, G.P.L. 1964. Crustal drift in Iceland. Geophysical Journal of the Royal Astronomical Society, 9: 285-300.

Bohannon, R.G. 1986. Tectonic configuration of the western Arabian continental margin, southern Red Sea. Tectonics, 5(4): 477-499.

Bohnhoff, M., and Makris, J. 2004. Crustal structure of the southeastern IcelandFaeroe Ridge (IFR) from wide aperture seismic data. Journal of Geodynamics, 37: 233-252. doi:10.1016/j.jog.2004.02.004.

Bosworth, W. 1987. Off-axis volcanism in the Gregory rift, east Africa:

Implications for models of continental rifting. Geology, 15: 397-400.

Boudier, F., and Nicolas, A. 2011. Axial melt lenses at oceanic ridges - A case study in the Oman Ophiolite. Earth and Planetary Science Letters, 304: 313325.

Bown, J.W., and White, R.S. 1994. Variation with spreading rate of oceanic crustal thickness and geochemistry. Earth and Planetary Science Letters, 121: $435-439$.

Brandsdóttir, B., and Menke, W.H. 2008. The seismic structure of Iceland. Jökull, 58: 17-34. 
Bunch, A.W.H., and Kennett, B.L.N. 1980. The crustal structure of the Reykjanes Ridge at $59^{\circ} 30^{\prime} \mathrm{N}$. Geophysical Journal of the Royal Astronomical Society, 61: 141-166.

Burke, K. 1977. Aulacogens and continental break-up. Annual Review of Earth and Planetary Sciences, 5: 371-396.

Burke, K., and Dewey, J.F. 1973. Plume-generated triple junctions: Key indicators in applying plate tectonics to old rocks. Journal of Geology, 81: 406-433.

Casey, J.F., Dewey, J.F., Fox, P.J., Karson, J.A., and Rosencrantz, E. 1981. Heterogeneous nature of the oceanic crust and upper mantle: A perspective from the Bay of Islands Ophiolite. In The Oceanic Lithosphere. Edited by C. Emiliani. Wiley, New York. pp. 305-338.

Christeson, G.L., Purdy, G.M., and Fryer, G.J. 1994. Seismic constraints on shallow crustal emplacement processes at the fast spreading East Pacific Rise. Journal of Geophysical Research, 99: 17957-17974.

Coffin, M.F., and Eldholm, O. 1994. Large igneous provinces: Crustal structure, dimensions and external consequences. Reviews of Geophysics, 32: 1-36.

Cox, K.G. 1980. A model for flood basalt vulcanism. Journal of Petrology, 21: 629-650.

Darbyshire, F.A., Bjarnason, T., White, R.S., and Flóvenz, O.G. 1998. Crustal structure above the Iceland mantle plume imaged by the ICEMELT refraction profile. Journal of Geophysical Research, 135: 1131-1149. 
Darbyshire, F.A., Priestley, K.F., White, R.S., Stefánsson, R., Gudmundsson, G.B., and Jakobsdóttir, S.S. 2000a. Crustal structure of central and northern Iceland from analysis of teleseismic receiver functions. Geophysical Journal International, 143: 163-184.

Darbyshire, F.A., White, R.S., and Priestley, K.F. 2000b. Structure of the crust and uppermost mantle of Iceland from a combined seismic and gravity study. Earth and Planetary Science Letters, 181(3): 409-428.

Dewey, J.F., and Burke, K.C.A. 1974. Hot spots and continental break-up: implications for collisional orogeny. Geology, 2: 57-60.

Ebinger, C.J. 1989. Tectonic development of the western branch of the East African Rift system. Geological Society of America Bulletin, 101: 885-903. Einarsson, P. 1991. Earthquakes and present-day tectonism in Iceland.

Tectonophysics, 189: 261-279.

Einarsson, P. 2008. Plate boundaries, rifts and transforms in Iceland. Jökull, 58: $35-58$.

Elliot, D. 1983. The construction of balanced cross-sections. Journal of Structural Geology, 5: 101.

Franke, D. 2013. Rifting, lithosphere breakup and volcanism: Comparison of magma-poor and volcanic rifted margins. Marine and Petroleum Geology, 43: $63-87$.

Garcia, S., Angelier, J., Bergerat, F., and Homberg, C. 2002. Tectonic analysis of an oceanic transform fault zone based on fault-slip data and earthquake 
focal mechanisms: The Húsavík-Flatey Fault zone, Iceland. Tectonophysics, 344: 157-174.

Garcia, S., Arnaud, N.O., Angelier, J., Bergerat, F., and Homberg, C. 2003. Rift jump process in Northern Iceland since $10 \mathrm{Ma}$ from $40 \mathrm{Ar} / 39 \mathrm{Ar}$ geochronology. Earth and Planetary Science Letters, 214: 529-544.

Geoffroy, L. 2005. Volcanic passive margins. Comptes Rendus Geosciences, 337: 1395-1408. doi: 10.1016 /j .crte.2005.10.006.

Gibbs, A.D. 1983. Balanced cross section construction from seismic sections in areas of extensional tectonics. Journal of Structural Geology, 5: 153-160.

Green, R.G., White, R.S., and Greenfield, T. 2014. Motion in the north Iceland volcanic rift zone accommodated by bookshelf faulting. Nature Geoscience, 7: 29-33. doi:10.1038/ngeo2012.

Hardarson, B.S., Fitton, J.G., Ellam, R.M., and Pringle, M.S. 1997. Rift relocation: A geochemical and geochronological investigation of a palaeo-rift in northwest Iceland. Earth and Planetary Science Letters, 153: 181-196.

Hey, R.N. 2004. Propagating rifts and microplates at mid-ocean ridges. In Encylopedia of Geology. Edited by R.C. Selley. Academic Press, London. pp. 396-405.

Hirth, G.A., Escartín, J., and Lin, J. 1998. Rheology of the lower oceanic crust: Implications for lithospheric deformation at mid-ocean ridges. In Faulting and Magmatism at Mid-Ocean Ridges. Edited by W.R. Buck and P.T. Delaney and J.A. Karson and Y. Lagabrielle. American Geophysical Union, Washington, DC. pp. 291-303. 
Hjartardóttir, A.R., Einarsson, P., Bramham, E., and Wright, T.J. 2012. The Krafla fissure swarm, Iceland, and its formation by rifting events. Bulletin of Volcanology, 74: 2139-2153.

Hjartardóttir, Á.R., Einarsson, P., Magnúsdóttir, S., Björnsdóttir, P., and Brandsdóttir, B. 2015. Fracture systems of the Northern Volcanic Rift Zone, Iceland: an onshore part of the Mid-Atlantic plate boundary. Geological Societty of London, Special Publications 420. doi:10.1144/SP420.1. Holbrook, W.S., and Keleman, P.B. 1993. The U.S. East Coast margin igneous province. Nature, 364: 433-436.

Hooft, E.E.E., Brandsdóttir, B., Mjelde, R., Shimamura, H., and Murai, Y. 2006. Asymmetric plume-ridge interaction around Iceland: The Kolbeinsey Ridge Iceland Seismic Experiment. Geochemistry, Geophysics, and Geosystems, 7(Q05015). doi:10.1029/2005GC001123.

Hopper, J.R., and Buck, W.R. 1996. The effect of lower crustal flow on continental extension and passive margin formation. Journal of Geophysical Research, 101: 20175-20194.

Hossack, J.R. 1979. The use of balanced cross-sections in the calculation of orogenic contraction: a review. Journal of the Geological Society of London, 136: 705-711.

Jacobsdóttir, S. 2008. Seismicity in Iceland 1994-2007. Jökull, 58: 75-102. Jones, S.M., and Maclennan, J. 2005. Crustal flow beneath Iceland. Journal of Geophysical Research, 110(B9). doi: 10.1029/2004JB003592. 
Karson, J.A. 2002. Geologic structure of uppermost oceanic crust created at fastto intermediate-rate spreading centers. Annual Review of Earth and Planetary Sciences, 30: 347-384.

Karson, J.A. 2015. Consequences of rift propagation for spreading in thick oceanic crust in Iceland. Eos Transactions of the American Geophysical Union, Fall Meeting Supplement: T43H-07.

Karson, J.A. 2016. The Iceland plate boundary zone: Propagating rifts, migrating transforms and microplates. in preparation.

Karson, J.A., and Brooks, C.K. 1999. Structural and magmatic segmentation of the Tertiary East Greenland volcanic rifted margin. In Continental Tectonics. Edited by P. Ryan and C. MacNiocaill. Blackwell Scientific Publishers, London. pp. 313-338.

Karson, J.A., Kelley, D.S., Fornari, D.J., Perfit, M.R., and Shank, T.M. 2015. Discovering the Deep: A Photographic Atlas of the Seafloor and Oceanic Crust. Cambridge University Press, London. pp. 414.

Kelemen, P.B., and Holbrook, W.S. 1995. Origin of thick, high-velocity igneous crust along the U.S. East Coast Margin. Journal of Geophysical Research, 100: $10,077-010,094$.

Kelemen, P.B., Koga, K., and Shimizu, N. 1997. Geochemistry of gabbro sills in the crust/mantle transition zone of the Oman ophiolite: implications for the origin of the oceanic lower crust. Earth and Planetary Science Letters, 146: 475-488. 
Klausen, M.B., and Larsen, H.C. 2002. East Greenland coast-parallel dike swarm and its role in continental breakup. Geological society of America Special Paper, 362: 133-158.

Korenaga, J., Holbrook, W.S., Kent, G.M., Kelemen, P.B., Detrick, R.S., Larsen, H.-C., Hopper, J.R., and Dahl-Jensen, T. 2000. Crustal strucutre of the southeast Greenland margin from joint refraction and reflection seismic tomography. Journal of Geophysical Research, 105: 21591-21614.

Korenaga, J., Kelemen, P.B., and Holbrook, W.S. 2002. Methods for resolving the origin of large igneous provinces from crustal seismology. Journal of Geophysical Research, 107(B9). doi:10.1029/2001JB001030.

Larsen, H.C., and Jakobsdóttir, S. 1988. Distribution, crustal properties and significance of seawards-dipping sub-basement reflectors off E Greenland. In Early Tertiary Volcanism and the Opening of the NE Atlantic. Edited by A.C. Morton and L.M. Parson. Geological Society of London, Special Publications 39, London. pp. 95-114.

Lipman, P.W., Clague, D.A., Moore, J.G., and Holcomb, R.T. 1989. South Arch volcanic field—Newly identified young lava flows on the sea floor south of the Hawaiian Ridge. Geology, 17: 611-614.

Maclennan, J., Hulme, T., and Singh, S.C. 2005. Cooling the lower oceanic crust. Geology, 5(doi: 10.1130/G21207): 357-360.

Maclennan, J., McKenzie, D., Grönvold, K., Shimizu, N., Eiler, J.M., and Kitchen, N. 2003. Melt mixing and crystallization under Theistareykir, northeast 
Iceland. Geochemistry, Geophysics, and Geosystems, 4(11).

doi:10.1029/2003GC000558.

Maclennan, J., McKenzie, D., Gronvold, K., and Slater, L. 2001. Crustal accretion under northern Iceland. Earth and Planetary Science Letters, 191: 295-310.

McKenzie, D.P., Nimmo, F., Jackson, J., Gans, P.B., and Miller, E. 2000.

Characteristics and consequences of flow in the crust. Journal of Geophysical Research, 105: 11029-11046.

Menzies, M.A., Klemperer, S.I., Ebinger, C.J., and Baker, J. 2002.

Characteristics of volcanic rifted margins. In Volcanic Rifted Margins. Edited by M.A. Menzies and S.I. Klemperer and C.J. Ebinger and J. Baker.

Geological Society of America, Boulder, CO. pp. 1-14.

Moores, E.M., and Vine, F.J. 1971. The Troodos massif, Cyprus, and other ophiolites as oceanic crust: evaluation and implications. Philosophical Transactions of the Royal Society of London, A268: 443-466.

Mutter, C.Z., and Mutter, J.C. 1993. Variation in thickness of layer 3 dominates oceanic crustal structure. Earth and Planetary Science Letters, 117: 295317.

Mutter, J.C. 1985. Seaward dipping reflectors and the continent-ocean boundary at passive continental margins. Tectonophysics, 114: 117-131.

Nicolas, A. 1989. Structure of Ophiolites and Dynamics of Oceanic Lithosphere. Kluwer Academic Press, Dordrecht, The Netherlands. 
Nicolas, A., Boudier, F., and Ildefonse, B. 1996. Variable crustal thickness in the Oman ophiolite: Implications for oceanic crust. Journal of Geophysical Research, 101: 17,941-917, 950.

Nielsen, T.F.D. 1978. The Tertiary dike swarm of the Kangerlussuaq area, East Greenland: An example of magmatic development during continental breakup. Contributions to Mineralogy and Petrology, 67: 63-78.

Nielsen, T.F.D., and Brooks, C.K. 1981. THe East Greenland rifted continental margin: An examination of the coastal flexure. Journal of the Geological Society of London, 138: 559-568.

Pálmason, G., Arnorsson, S., Fridleifsson, I.B., Kristmannsdottir, H., Saemundsson, K., Stefansson, V., Steingrimsson, B., Tomasson, J., and Kristjansson, L. 1978. The Iceland crust: Evidence from drillhole data on structure and processes. In Deep Drilling Results in the Atlantic Ocean: Ocean Crust. Edited by M. Talwani and C.G. Harrision and D.E. Hayes. Ewing Series, v. 2, American Geophysical Union. pp. 43-65.

Pálmason, G.A. 1986. Model of crustal formation in Iceland, and application to submarine mid-ocean ridges. In The Geology of North America. Edited by P.R. Vogt and B.E. Tucholke. Geological Society of America, Boulder, CO. pp. 87-97.

Peron-Pinvidic, G., Manatschal, G., and Osmundsen, P.T. 2013. Structural comparison of archetypical Atlantic rifted margins: A review of observations and concepts. Marine and Petroleum Geology, 43: 21-47. 
Planke, S., Symonds, P.A., Alvestad, E., and Skogseid, E. 2000. Seismic volcanostratigraphy of large-volume basaltic extrusive complexes on rifted margins. Journal of Geophysical Research, 105(B8): 19335-19351.

Quick, J.E., and Denlinger, R.P. 1993. Ductile deformation and the origin of layered gabbro in ophiolites. Journal of Geophysical Research, 98: 1401514027.

Quirk, D.G., Shakerley, A., and Howe, M.J. 2014. A mechanism for construction of volcanic rifted margins during continental breakup. Geology, 42: 10791082. doi: $10.1130 / G 35974$.

Reston, T.J. 2009. The structure, evolution and symmetry of the magma-poor rifted margins of the North and Central Atlantic: A synthesis. Tectonophysics, 468: 6-27. doi:10.1016/j.tecto.2008.09.002.

Rizert, M., and Jacoby, W.R. 1985. On the lithospheric seismic structure of Reykjanes Ridge at $62.5^{\circ} \mathrm{N}$. Journal of Geophysical Research, 90: 1011710128.

Rosendahl, B.R. 1987. Architecture of continental rifts with special reference to East Africa. Annual Reviews of Earth and Planetary Sciences, 15: 445-503. Royden, L.H., and Burchfiel, B.C. 1987. Thin-skinned N-S extension within the convergent Himalayan region: Gravitational collapse of a Miocene topographic front. In Continental Extensional Tectonics. Edited by M.P. Coward and J.F. Dewey and P.L. Hancock. Geological Society of London, London. pp. 611-619. 
Sæmundsson, K. 1974. Evolution of the axial rifting zone in northern Iceland and the Tjörnes Fracture Zone. Geological Society of America Bulletin, 85: 495504.

Sæmundsson, K. 1978. Fissure swarms and central volcanoes of the neovolcanic zones of Iceland. Geological Journal, 10: 415-432.

Sæmundsson, K. 1979. Outline of the geology of Iceland. Jökull, 29: 7-28.

Sæmundsson, K. 1986. Subaerial volcanism in the western North Atlantic. In The Western North Atlantic Region. Edited by P.R. Vogt and B.E. Tuchoke. Geological Society of America, Boulder, CO. pp. 69-86.

Searle, R.C., Keeton, J.A., Owens, R.B., White, R.S., Mecklenburgh, R., Parsons, B., and Lee, S.M. 1998. The Reykjanes Ridge: structure and tectonics of a hot-spot-influenced, slow-spreading ridge, from multibeam bathymetry, gravity and magnetic investigations. Earth and Planetary Science Letters, 160: 463-478.

Sengor, A.M.C., and Burke, K. 1978. Relative timing of rifting and volcanism on Earth and its tectonic implications. Geophysical Research Letters, 5(6): 419421.

Sinha, M.C., Constable, S.C., Peirce, C., White, A., Heinson, G., MacGregor, L.M., and Navin, D.A. 1998. Magmatic processes at slow spreading ridges: Implications of the RAMESSES experiment at $57^{\circ} 45^{\prime} \mathrm{N}$ on the Mid-Atlantic Ridge. Geophysical Journal International, 135: 731-745.

Smallwood, J.R., Staples, R.K., Richardson, K.R., White, R.S., and Group, F.W. 1999. Crust generated above the Iceland mantle plume: From continental rift 
to oceanic spreading center. Journal of Geophysical Research, 104: 2288522902.

Smallwood, J.R., White, R.S., and Minshull, T.A. 1995. Sea-floor spreading in the presence of the Iceland plume: the structure of the Reykjanes Ridge at $61^{\circ} 40^{\prime} \mathrm{N}$. Journal of Geology Soc., London, 152: 1023-1029.

Soosalu, H., Key, J., White, R.S., Knox, C., Einarsson, P., and Jakobsdóttir, S.S. 2010. Lower-crustal earthquakes caused by magma movement beneath Askja volcano on the north Iceland rift. Bull. Volcanol., 72: 55-62. DOI 10.1007/s00445-009-0297-3.

Stefánsson, R., Bodvarsson, R., Slunga, R., Einarsson, P., Jakobsdóttir, S., Bungun, H., Gregersen, S., Hjelme, J., and Korhonen, H. 1993. Earthquake prediction research in the South Iceland Seismic Zone and the SIL project. Bulletin of the Seismological Society of America, 83: 696-716.

Walker, G.P.L. 1957. Geology of the Reydarfjördur area, eastern Iceland.

Quarterly Journal of the Geological Society of London, 114(3): 367-393.

Walker, G.P.L. 1960. Zeolite zones and dike distribution in relation to the structure of the basalts of Eastern Iceland. Journal of Geology, 68(5): 515528.

Walker, G.P.L. 1964. Geological investigations in eastern Iceland. Bulletin of Volcanology, 27(1): 351.

Wernicke, B. 1981. Low-angle normal faults in the Basin and Range province: nappe tectonics in an extending orogen. Nature, 291: 645-648. 
White, R.S., and McKenzie, D. 1995. Mantle plumes and flood basalts. Journal of Geophysical Research, 100: 17543-17585.

White, R.S., and McKenzie, D.P. 1989. Magmatism in rift zones: The generation of volcanic continental margins and flood basalts. Journal of Geophysical Research, 94: 7685-7729.

White, R.S., Smith, L.K., Roberts, A.W., Chirstie, P.A.F., Kuznir, N.J., and iSIMM Team. 2008. Lower-crustal intrusion on the North Atlantic continental margin. Nature, 452. doi:10.1038/nature06687.

White, R.S., Spence, G.D., Fowler, S.R., McKenzie, D.P., Westbrook, G.K., and Bowen, A.N. 1987. Magmatism at rifted continental margins. Nature, 330: 439-444.

Wolfe, C.J., Bjarnason, I.T., VanDecar, J.C., and Solomon, S.C. 1997. Seismic structure of the Iceland mantle plume. Nature, 385: 245-247.

\section{Figure Captions}

Fig. 1. Generalized schematic diagram showing the major features of a Volcanic Rifted Margin. Continental crust intruded by basaltic dikes and sills underlies subaerial pre- to syn-rift lavas. Lava flows dip seaward because of subsidence of dense, rifted and intruded pre-rift crust. Seaward, thick mafic igneous crust composed of gabbroic and ultramafic material underlies basaltic lavas with flows that dip and thicken seaward. The thick mafic crust passes laterally into thick 
oceanic crust beneath hotspot ridges or normal oceanic crust. Note that the volume of mafic and ultramafic intrusive rocks is likely to be substantially greater than that of overlying basaltic lavas and dikes.

Fig. 2. Iceland is situated over a hotspot between the Reykjanes Ridge (RR) and Kolbeinsey Ridge (KR). Iceland and its shallow platform lie on the hotspot ridge spanning the NE Atlantic; GIR- Greenland-Iceland Ridge; FIR- Faeroe-Iceland Ridge. Numbers indicate locations of seismic data in Figure 3.

Fig. 3. Representative two-layer columnar sections of areas in the NE Atlantic region ranging from very thick mafic igneous crust to normal oceanic crust. Upper crust $(\mathrm{V} p<6.5 \mathrm{~km} / \mathrm{sec})$ is inferred to be basaltic lavas and dikes; Lower crust $(6.5<\mathrm{V} p<7.6 \mathrm{~km} / \mathrm{sec})$ over depleted upper mantle. See Figure 2 for locations (2525 are not in the map area). a. Iceland: 1-6 with increasing distance from the hotspot (Darbyshire et al. 2000a), b. Platform and crust from Kolbeinsey Ridge (Hooft et al. 2006); c. Reykjanes Ridge (Bunch and Kennett 1980; Rizert and Jacoby 1985; Sinha et al. 1998); d. East Greenland Margin: 15-transition zone, 16-thick oceanic crust (Korenaga et al. 2000); e. Faeroe-Iceland Ridge (Bohnhoff and Makris 2004; Smallwood et al. 1999; White et al. 2008); f. Hatton Bank (White et al. 2008); g. Vøring Margin (Mutter and Mutter 1993); h. Average oceanic crust (Bown and White 1994). 
Fig. 4. Generalized tectonic map of Iceland and Iceland platform (light gray) showing the complex plate boundary zone above thick mafic igneous crust. The post-glacial neovolcanic zone (NVZ) is made up an array of volcano-tectonic units consisting of central volcanoes, fissure/dike swarms and normal faults. The Eastern Rift Zone (ERZ) and Northern Rift Zone (NRZ) propagate to the S and N (bold arrows), respectively, away from the hotspot located beneath central Iceland resulting in migrating transform zones, abandoned spreading centers, and large-scale block rotations. Rotations are accommodated by widespread (spreading-related?) strike-slip faults parallel to local dikes. Half-arrows show the locations and sense of shear of strike-slip fault zones. Crustal thickness contours (fine dashed lines) show very thick crust ( $40 \mathrm{~km}$ thick) above the center of the hotspot that passes laterally into thinner crust ( 20-25 km thick) outside the NVZ (Darbyshire et al. 2000b). CRZ- Central Rift Zone; SVZ- Snæfellsnes Volcanic Zone; WRZ- Western Rift Zone; SISZ- S. Iceland Seismic Zone; HFF- HusavikFlatey Fault; GFZ- Grimsey Fault Zone.

Fig. 5. Schematic diagram summarizing processes related to the construction and modification of very thick mafic igneous crust in places like Iceland or along VRMs. Complex spreading and transform kinematics in the rigid upper crust including propagating rifts, migrating transform faults and rotated crustal blocks, are decoupled from weak, ductile lower crust that reduces lower crustal thickness variations by along-axis flow. 
Fig. 6. Formation of rifted continental margins at hotspot uplifts (Burke and Dewey 1973). a. Initial rifting and volcanism near hotspots. b. Locations of thick mafic crust along VRMs where complex 3D spreading processes similar to Iceland may occur. Out of plane (along-axis) lower crustal flow and upper crustal rift-parallel, strike-slip faulting are likely to affect the overlying syn-rift sedimentary section (stippled). Hotspots remaining on spreading ridges create ridges of thick crust leading back to the initial hotspot location. 


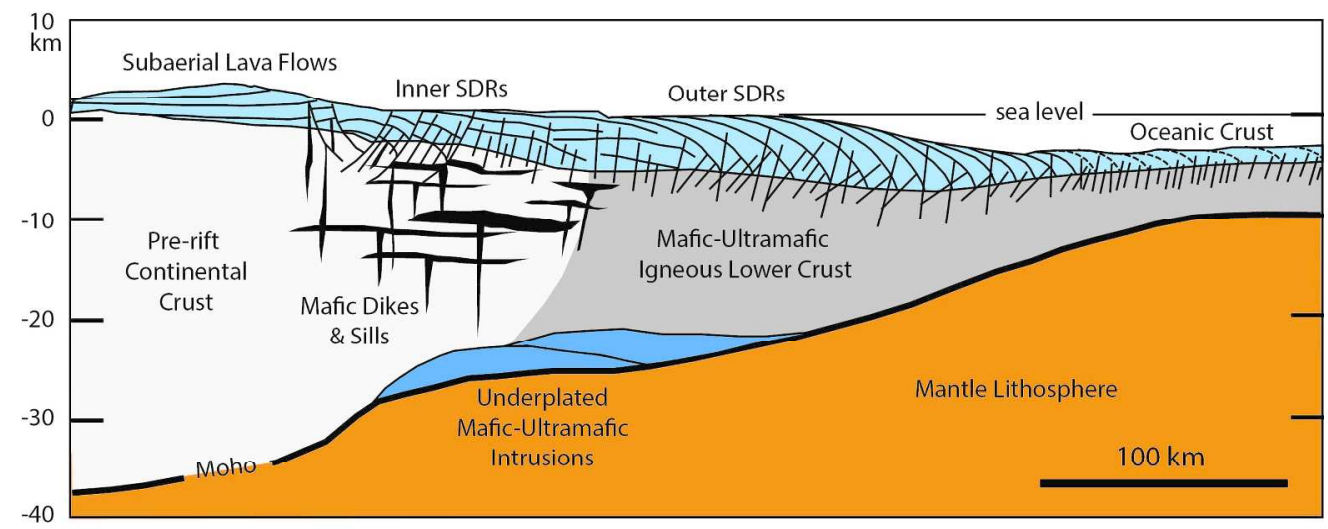

Figure 1

Fig. 1. Generalized schematic diagram showing the major features of a Volcanic Rifted Margin. Continental crust intruded by basaltic dikes and sills underlies subaerial pre- to syn-rift lavas. Lava flows dip seaward because of subsidence of dense, rifted and intruded pre-rift crust. Seaward, thick mafic igneous crust composed of gabbroic and ultramafic material underlies basaltic lavas with flows that dip and thicken seaward. The thick mafic crust passes laterally into thick oceanic crust beneath hotspot ridges or normal oceanic crust. Note that the volume of mafic and ultramafic intrusive rocks is likely to be substantially greater than that of overlying basaltic lavas and dikes. $219 \times 122 \mathrm{~mm}(300 \times 300 \mathrm{DPI})$ 


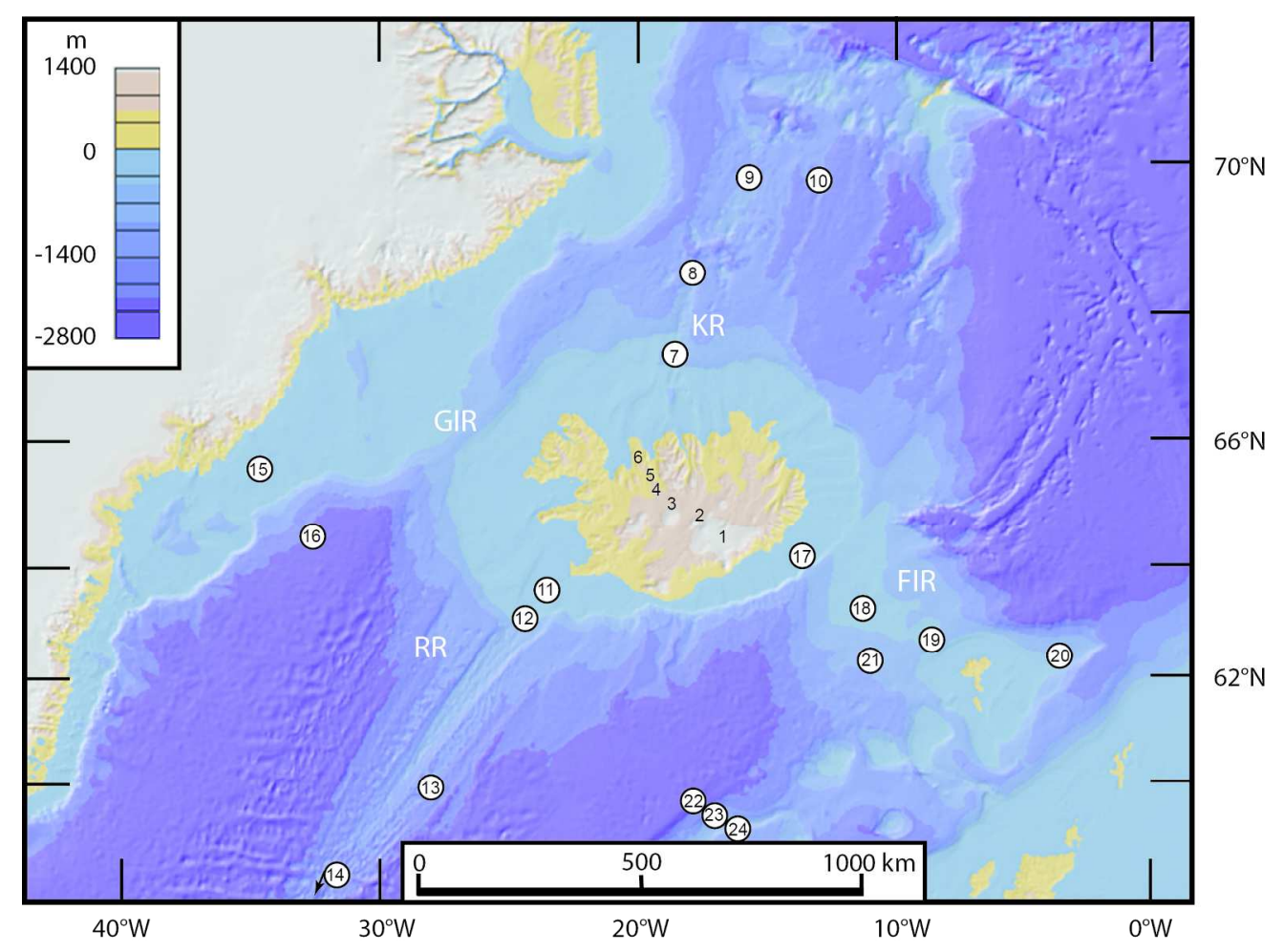

Figure 2

Fig. 2. Iceland is situated over a hotspot between the Reykjanes Ridge (RR) and Kolbeinsey Ridge (KR). Iceland and its shallow platform lie on the hotspot ridge spanning the NE Atlantic; GIR- Greenland-Iceland Ridge; FIR- Faeroe-Iceland Ridge. Numbers indicate locations of seismic data in Figure 3. $200 \times 163 \mathrm{~mm}(300 \times 300 \mathrm{DPI})$ 


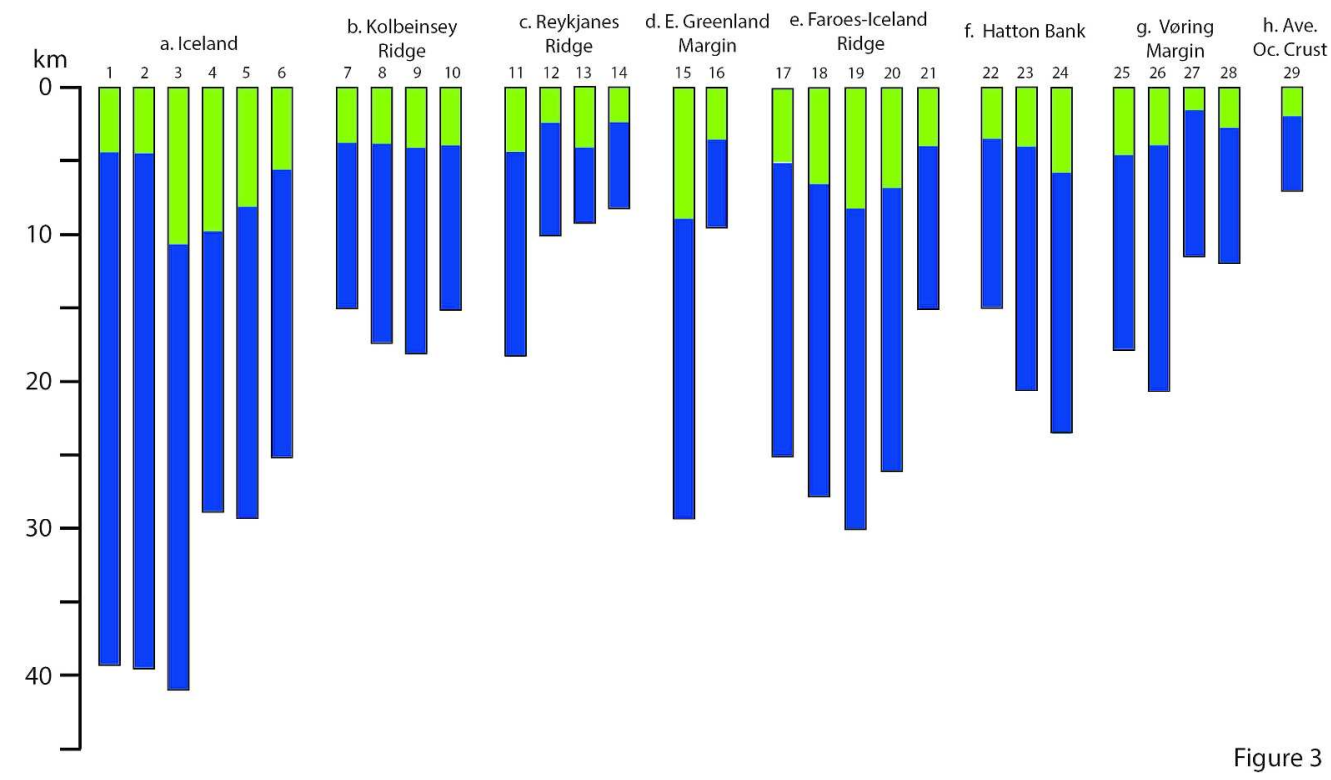

Fig. 3. Representative two-layer columnar sections of areas in the NE Atlantic region ranging from very thick mafic igneous crust to normal oceanic crust. Upper crust $(\mathrm{Vp}<6.5 \mathrm{~km} / \mathrm{sec})$ is inferred to be basaltic lavas and dikes; Lower crust $(6.5<\mathrm{Vp}<7.6 \mathrm{~km} / \mathrm{sec})$ over depleted upper mantle. See Figure 2 for locations (25-25 are not in the map area). a. Iceland: 1-6 with increasing distance from the hotspot (Darbyshire et al. 2000a), b. Platform and crust from Kolbeinsey Ridge (Hooft et al. 2006); c. Reykjanes Ridge (Bunch and Kennett 1980; Rizert and Jacoby 1985; Sinha et al. 1998); d. East Greenland Margin: 15-transition zone,

16-thick oceanic crust (Korenaga et al. 2000); e. Faeroe-Iceland Ridge (Bohnhoff and Makris 2004; Smallwood et al. 1999; White et al. 2008); f. Hatton Bank (White et al. 2008); g. Vøring Margin (Mutter and Mutter 1993); h. Average oceanic crust (Bown and White 1994).

$275 \times 161 \mathrm{~mm}(300 \times 300 \mathrm{DPI})$ 


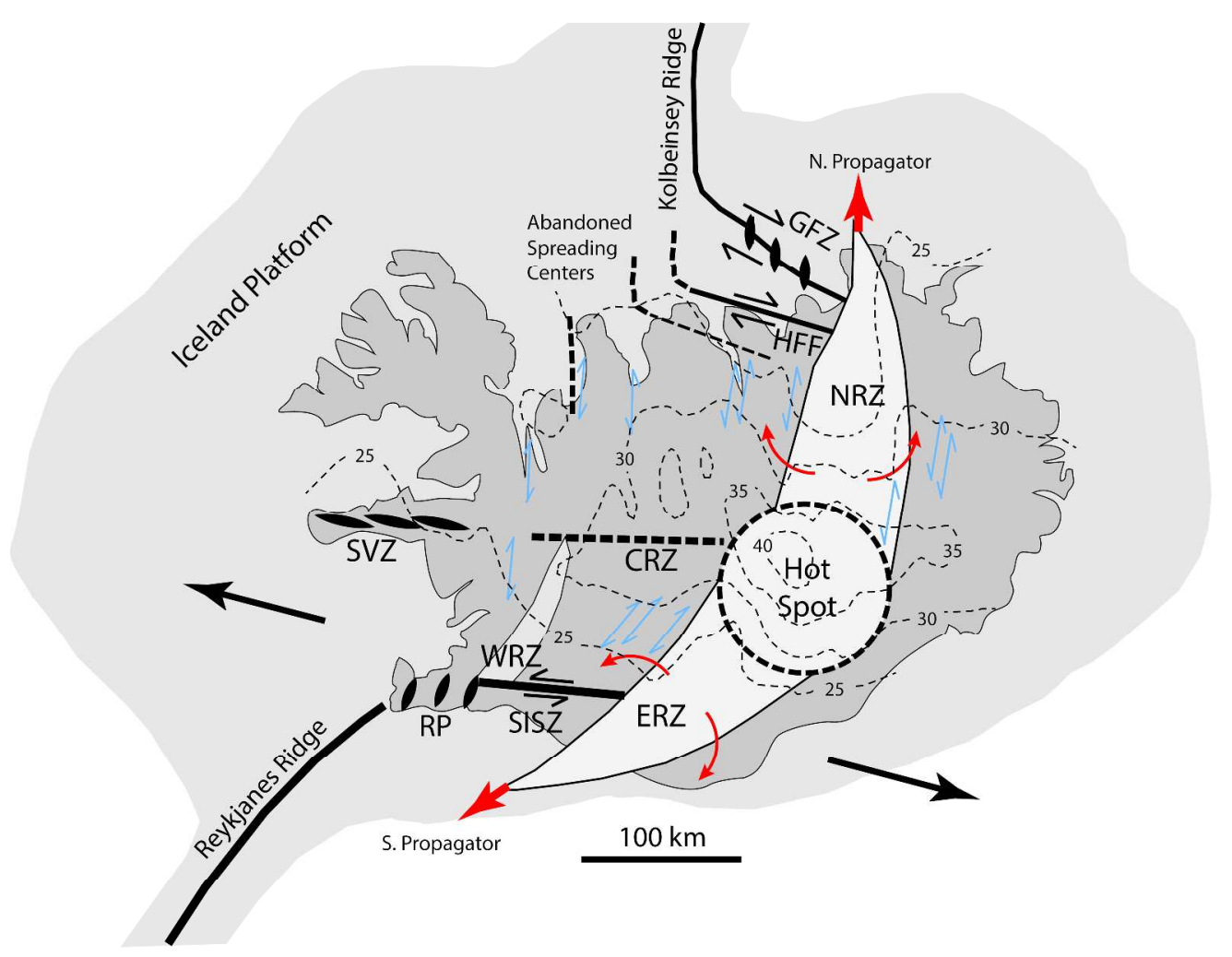

Figure 4

Fig. 4. Generalized tectonic map of Iceland and Iceland platform (light gray) showing the complex plate boundary zone above thick mafic igneous crust. The post-glacial neovolcanic zone (NVZ) is made up an array of volcano-tectonic units consisting of central volcanoes, fissure/dike swarms and normal faults. The Eastern Rift Zone (ERZ) and Northern Rift Zone (NRZ) propagate to the S and N (bold arrows), respectively, away from the hotspot located beneath central Iceland resulting in migrating transform zones, abandoned spreading centers, and large-scale block rotations. Rotations are accommodated by widespread (spreadingrelated?) strike-slip faults parallel to local dikes. Half-arrows show the locations and sense of shear of strikeslip fault zones. Crustal thickness contours (fine dashed lines) show very thick crust ( $40 \mathrm{~km}$ thick) above the center of the hotspot that passes laterally into thinner crust ( $\sim 20-25 \mathrm{~km}$ thick) outside the NVZ (Darbyshire et al. 2000b). CRZ- Central Rift Zone; SVZ- Snæfellsnes Volcanic Zone; WRZ- Western Rift Zone; SISZ- S. Iceland Seismic Zone; HFF- Husavik-Flatey Fault; GFZ- Grimsey Fault Zone. $396 \times 324 \mathrm{~mm}(300 \times 300$ DPI) 


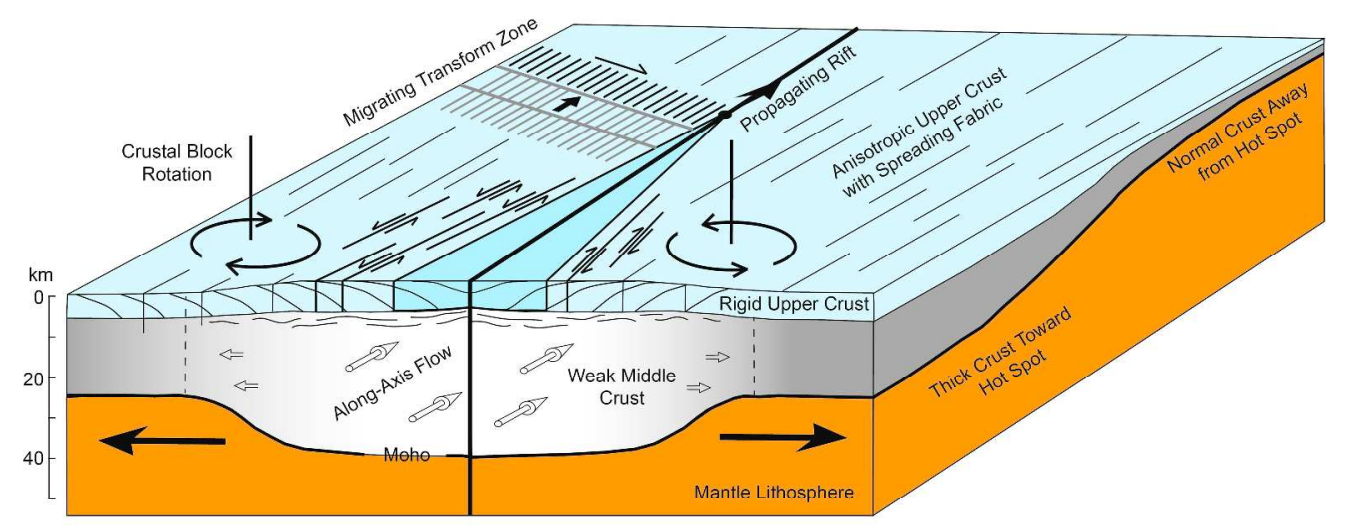

Figure 5

Fig. 5. Schematic diagram summarizing processes related to the construction and modification of very thick mafic igneous crust in places like Iceland or along VRMs. Complex spreading and transform kinematics in the rigid upper crust including propagating rifts, migrating transform faults and rotated crustal blocks, are decoupled from weak, ductile lower crust that reduces lower crustal thickness variations by along-axis flow. $438 \times 204 \mathrm{~mm}(300 \times 300$ DPI $)$ 

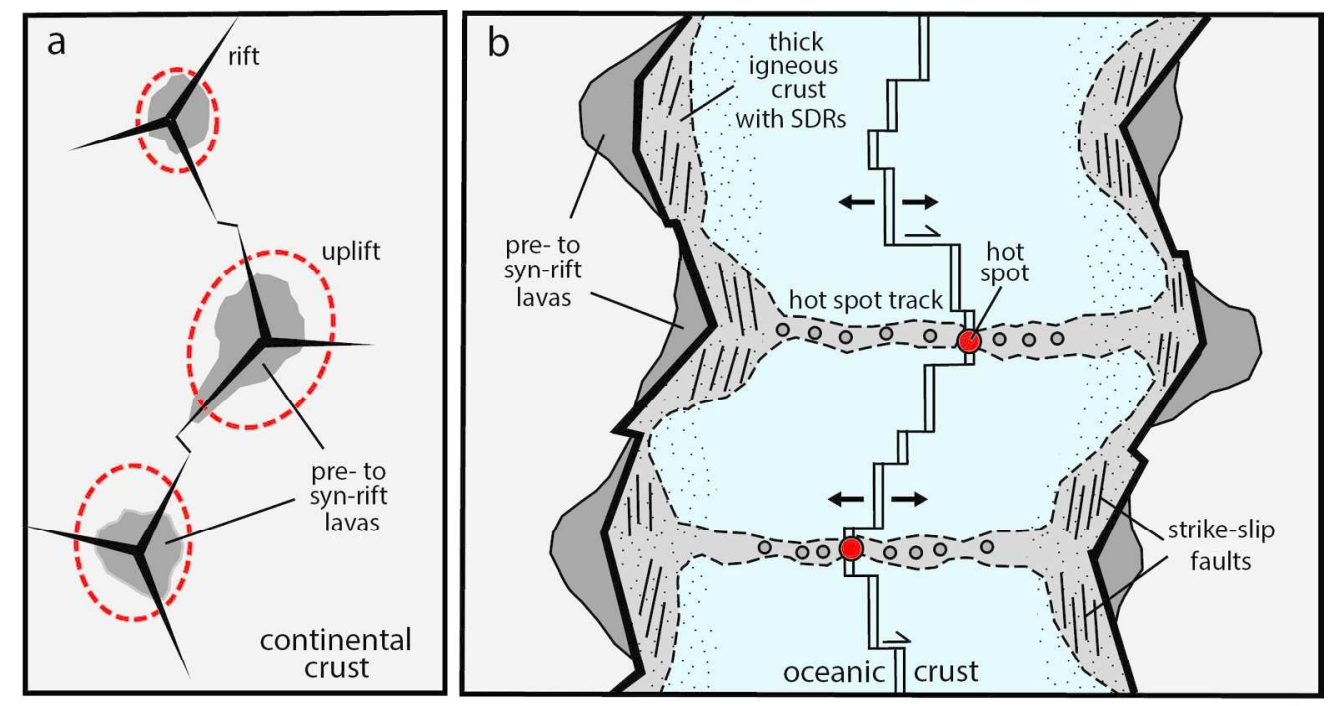

Figure 6

Fig. 6. Formation of rifted continental margins at hotspot uplifts (Burke and Dewey 1973). a. Initial rifting and volcanism near hotspots. b. Locations of thick mafic crust along VRMs where complex 3D spreading processes similar to Iceland may occur. Out of plane (along-axis) lower crustal flow and upper crustal riftparallel, strike-slip faulting are likely to affect the overlying syn-rift sedimentary section (stippled). Hotspots remaining on spreading ridges create ridges of thick crust leading back to the initial hotspot location. $171 \times 102 \mathrm{~mm}(300 \times 300$ DPI $)$ 